\title{
Memory, Management and Marketing: Heritage Tourism as a Catalyst for Urban Transformation
}

\author{
Matthew W. Rofe \\ School of Natural and Built Environments, University of South Australia, Australia \\ matthew.rofe@unisa.edu.au
}

\begin{abstract}
World heritage status ratifies the enduring significance of a specific place for all of humanity. Inscription on the UNESCO World Heritage register not only formally recognises the local, national and international importance of place, but equally creates a range of externalities that are often construed to be positive and hence desirable. Foremost amongst these are the economic benefits purported to flow from tourism. Within the wider pantheon of tourism, world heritage tourism is a rapidly growing niche market. The logic follows that the economic benefits generated through world heritage tourism can, in part, be invested into the development and management of the site so as to preserve it for future generations to enjoy. However, the reality is much more complex. World Heritage tourism is in fact a double-edged sword. With increased visitations come the risk of over-crowding, an erosion of the very features and amenities that underpin the designation and possibly the commodification of the site itself. Consequently, the careful management of world heritage sites is essential to ensure that the impacts of world heritage tourism are mitigated. This chapter critically engages with these challenges, drawing upon a case study of the World Heritage core of George Town, Penang.
\end{abstract}

\section{Introduction}

Cities have emerged as key tourism sites (see Edwards et al., 2008). As the principle spaces of human habitation and history this is not surprising. Karski (1990, p.15) noted the complexity of cities as a critical motivating factor in attracting tourists, observing that:

People with the means and inclination to do so have been drawn to... cities just to visit and experience a multiplicity of things to see and do. [Cities are] the melting pots of national culture, art, music, literature and of course magnificent architecture.... It... [is] the concentration, variety, and quality of these activities and attributes... that... put... cities on the tourism map.

Karski (1990) here draws upon both the tangible (physical) and intangible (cultural) aspects of the city in broadly outlining those qualities that attract tourists. In reality, the attraction factors and motivations driving urban tourism are as diverse as the individual nature and character of cities themselves. This represents a challenge for the conceptualisation of urban tourism, for as Ashworth and Page (2011, p.2) have noted '[a]dding the adjective urban to the noun tourism locates an activity in a spatial context but does not in itself define or delimit that activity.' Urban tourism therefore remains a complex phenomenon. Cognoscente of this, this paper investigates urban-based heritage tourism. Specifically, it explores World Heritage (WH) tourism within urban contexts. While WH status has been construed as a 'magnet' that provides a given location with an '...effective differential advantage' (Fyall and Rakic 2006 p.163) in the tourism marketplace, it is also recognised as being beset by a range of challenges. Drawing upon the example of the WH core of George Town, Penang this paper explores these opportunities and challenges. The case of George Town is extremely salient for its inscription on the $\mathrm{WH}$ register is on the basis of both its built urban heritage and complex and diverse social fabric. Thus, George Town is said to embody a living cultural heritage site. As the paper contends, managing this complexity is paramount in order to preserve George 
Town's heritage in a sensitive manner so as to sustain it into the future.

\section{Urban Tourism, Preservation and World Heritage}

As a specific research focus, urban tourism has been said to have languished in the shadow of rural tourism (see Ashworth 1989; Edwards et al. 2008; Ashworth and Page 2011). Ashworth (1989: 33) positioned this bias as a 'serious constraint' on the development of tourism studies more broadly. The origins of this bias stems from an 'antiurban' romanticism following the Industrial Revolution (Ashworth and Page 2011: 3). This romanticism, typically referred to as the rural idyll (see Winchester and Rofe 2005), privileged the rural as the natural preserve of wholesome values and experiences. Contrasting this, the urban was demonised as an unnatural, corrupting place characterised by declining social values. Rural spaces were thus seen as offering rejuvenating opportunities for weary urbanites and hence a more logical foci of research attention. Since Ashworth's (1989) call to redress this imbalance, a plethora of research has specifically addressed urban tourism (see for example Page 1995; Ashworth and Tunbridge 2000; Hayllar et al. 2008). Notwithstanding the advances presented by this rapidly growing literature, Ashworth and Page (2011: 13) contend that much is still to be done. In particular, they call for a greater engagement with '...urban studies and its theoretical critiques' (Ashworth and Page 2011: 13) (see also Edwards et al. 2008).

At the heart of these calls are a series of key recognitions about the complex nature of urban tourism. Ashworth and Page (2011: 78 ) define these as relating to the volatile and unpredictable nature of the urban tourism market. First amongst these is the selective nature of urban tourism, as urban tourists only use specific spaces of and facilities within the wider urban landscape. These spaces constitute 'central tourism districts' (Burtenshaw et al. (1991). Within the context of this paper it is noteworthy that Ashworth and Turnbridge (1990) perceive urban tourism oriented spaces as often correlating with historic landscapes. The specific nature of urban tourism in effect problematises the notion of a broader urban tourism experience and suggests that the benefits and impacts of such tourism are likely to be spatially concentrated. The second issue concerns the short-term nature of urban tourism. Urban tourism visitations are typically measured in hours as opposed to days when compared to other tourism forms. This time-compression has potential impacts for the realisation of the economic benefits purported to flow from tourist visitations. The third factor concerns repeat tourism. Ashworth and Page (2011) contend that many urban tourists are engaged in 'collecting' visitations to highly specific sites. Once 'collected' '... a repeat visit is superfluous and the place collection will be expanded elsewhere' (Ashworth and Page 2011: 8). The final recognition advanced is the capricious nature of the urban tourism market. Here, the fashion of and hence taste for a given urban tourism experience is subject to unpredictable market fluctuations. Although tourism generally is acknowledged as being vulnerable to shifting tastes and desires, Ashworth and Page (2011: 8) argue that ' $[\mathrm{t}]$ he popularity of historical periods, artistic styles and personalities waxes and wanes' and as a consequence the attractiveness of the specific nature of urban tourism products are vulnerable to changing consumer tastes.

Notwithstanding these issues, the promotion of tourism development remains a key policy direction the world over. Beyond its purported economic benefits (see Lim et.al, 2008), tourism is also construed to represent a vehicle for the conservation of both tangible and intangible heritage. As Hede (2008: 134) astutely notes, '[h]eritage and tourism appear to be strange bedfellows. Yet, there is increasing evidence of their coupling around the globe'. The oddity recognised here revolves around the implicit desire of heritage conversation to preserve as opposed to the explicit orientation of tourism to package and commodify. As a commodity, heritage is a consumable experience. Understanding 'consumption' here is critical, for to consume is '...to destroy, to use up, to waste, to exhaust' (Williams 1976: 68). While it is unlikely that heritage sites will be physically 'destroyed' and so 'wasted' through tourism, it 
must be noted that high tourism visitations coupled with poor site-specific conservation management can result in the physical degradation of heritage sites. In turn, this may undermine the perceived quality of the site within the tourism market-place and so initiate a decline in its market position. Beyond these physically-oriented issues are more ephemeral challenges. Consumption generally is not simply a '...process by which artefacts are ... 'consumed', but [are] given meaning through their incorporation in people's lives' (Jackson 1993: 209). This suggests a more dynamic relationship between heritage and urban tourism. In short, heritage tourists may well 'exhaust' the value of heritage tourism sites through the process of 'collecting' them.

Furthermore, it is vital not to assume that heritage is a natural nor neutral concept. Rather, '...heritage is a process through which select aspects of the past are, in the present, determined to be of future value and hence are protected through legislative processes' (Rofe et al., 2011: 97). Heritage then is a deliberative designation that involves value judgements that validate some things over others. In doing so, some histories are remembered, while others are, conveniently perhaps, forgotten. Thus, heritage implicitly involves the operation of power. This realisation ratifies Cameron's (2010: 203) assertion that ' $[\mathrm{h}]$ eritage is an unnatural phenomenon'.

Spearheading global heritage conservation is the United Nations Educational, Scientific and Cultural Organization's (UNESCO) World Heritage Convention (WHC). Introduced in 1972, the WHC provides a cross-jurisdictional legislative framework seeking to preserve those ' $\ldots$ places on Earth that are of outstanding universal value to humanity and as such, have been inscribed on the World Heritage List [WHL] to be protected for future generations to appreciate and enjoy' (http://whc.unesco.org/en/108\#world_heritage ). Expounding the importance of these sites, UNESCO argues that ' $[\mathrm{w}]$ hat makes the concept of World Heritage exceptional is its universal application. WH sites belong to all the peoples of the world, irrespective of the territory on which they are located' (http://whc.unesco.org/en/about/). In order words, WH status ratifies the importance of a local site across space and through time.

Presently, there are $1031 \mathrm{WH}$ sites globally. UNESCO recognises natural heritage, underwater heritage, cultural heritage, intangible heritage and moveable heritage. These categories are classified into the three broad groupings of cultural, natural and mixed heritage sites. Presently, there are 802 cultural, 197 natural and 32 mixed heritage sites across the globe (see http://whc.unesco.org/en/list). Beyond these, there are 1630 additional sites nominated on the Tentative List, which represents an inventory of sites developing formal inscription applications (see http://whc.unesco.org/en/tentativelists/).

Combined, these sites can be considered as constituting a global ark of fragile and irreplaceable landscapes.

However, beyond UNESCO's altruistic aspirations are a range of other motivations driving inscription on the World Heritage List. Foremost amongst these are the purported economic benefits said to stem from the emergence of $\mathrm{WH}$ oriented tourism as a niche market of overall global tourism (see for example Li et al. 2008; Boniface 1995; Poria et al. 2011). However, such a strategy is a double-edged sword. While WH status ratifies the global significance of a local site, the logic that this naturally translates into economic dividends is highly questionable. Investigating this assumed logic Poria et al. (2011) surveyed tourists' opinions of WH status as a determinant in visit motivation at the Basilica of the Annunciation at Nazareth, Northern Israel. Their findings refute the assertion that WH status is a 'guarantee' of increased tourism numbers and associated economic benefits. Instead, they conclude that the evidence actually runs contrary to the assumed logic and that World Heritage status may in fact constitute a detracting factor in tourism choice (Poria et al. 2011: 490). This may well stem from the fact that such sites can be perceived as attracting significant tourism numbers and so are over-crowded. Indeed, overcrowding is cited by Li et al. (2008: 308) as a problem for $\mathrm{WH}$ sites, observing that ' $[t]$ he success of the Convention has... caused a dilemma; increased visitation is now the primary threat to World Heritage Sites' (see 
also Garrod and Fyall 2000). Physical degradation of a site is an obvious manifestation of high tourist volume. Here, poor management is a key culprit. Beyond these, concerns must also be raised about negative impacts upon local communities dwelling either in or in close proximity to $\mathrm{WH}$ sites. Jenkins (2008: 247) considers that within cultural heritage sites tourism promotion constitutes a '...misappropriations of... cultural space for voyeuristic' commodified experiences. In effect, the daily lives of local people become subject to the gaze of tourists. The concern here is that cultural heritage sites may become living museums, where the lives of locals are subject to external intrusive surveillance. Thus, WH status embodies a complex and contested designation. While it undoubtedly assists in the preservation of sites, it is also bedevilled by negative factors that unless carefully managed have undesirable impacts. To illustrate these opportunities and pitfalls, this paper turns to a discussion of George Town's WH core.

\section{George Town, World Heritage City}

Palau Penang is located off the west coast of the Malaysian Peninsular. Its capital George Town, was founded by Capt. Francis Light in 1786 and rapidly emerged as a prominent Straights City along with Malacca and Singapore. From its founding, George Town has always been a multicultural city. Its' diverse racial and cultural composition, made up predominantly Malays, Europeans, Chinese (Cantonese, Hakkas, Hainanese and Hokkien) and Indians (Tamils, Bangalis and Parsis), created a rich and complex built and cultural landscape. As Nin (2001: 14) asserts, '[a]11 of these groups were active participants in the creation of a cosmopolitan city... [and] even today Penang is distinguished by the many ethnic minorities and historic communities which add to the richness of...' the city. Consequently Penang is lauded as the 'Pearl of the Orient'. This moniker is, in fact, largely a tourism discourse. The Penang State Government turned to tourism as a panacea to stem the economic decline associated with the removal of Penang's free-port status in the late 1960s and the repeal of the rent-control act in the late 1990s. Both of these events initiated economic decline within George Town. To bolster tourism investment tax incentives were developed and these witnessed the rapid expansion of hotel development by the masstourism industry (see Jenkins 2008). While undeniably successful, concerns were expressed regarding the scale and speed at which this development occurred. Yeoh (1996, cited in Jenkins 2008: 153) asserts that ' $[\mathrm{t}]$ he economic boom of Penang has strained its resources - the result...clogged-up streets... badly maintained tourist facilities and an airport that can hardly cope with one planeload of tourist arrival[s]'. This success initiated problems that were viewed by some as placing at risk George Town's unique architectural and cultural landscape. Indicative of this, the heritage core of George Town was named by World Monuments Watch in their World's Hundred Most Endangered Sites list in 1999.

In response to this perceived risk, lobbying began for the core of George Town to be declared a heritage conservation zone. Such a designation was perceived as a mechanism to preserve the areas diverse social composition while conserving the built landscapes of largely intact shop houses. Ultimately having George Town's core inscribed on the WHL was the explicit endgame of these activities. The pathway to inscription on the WHL is long and arduous, as George Town's experience attests. The first official UNESCO visit to advise on George Town's suitability as a WH applicant took place in 1998. This visit came shortly after the publication of UNESCO's Global Strategy for a Balanced Representative and Credible World Heritage List report (1994. See Jenkins 2008: 16). This report found that the List was predominantly comprised of European sites, that Christianity was predominant over other religions and that tangible took precedence over intangible heritage. To redress this imbalance, UNESCO courted applications from under-represented geographic regions and cultural groups. Thus the timing for George Town's foray into the $\mathrm{WH}$ inscription process was fortuitous. In the words of UNESCO's representative to George Town in 1998, Richard Englhardt, Malaysia represented a 'blank spot on the world heritage map' (Englhardt, cited in Jenkins 2008: 151). 
A decade after Englhardt's initial visit, George Town's heritage core was inscribed on the WHL in July 2008. To be precise, George Town is jointly inscribed on the List with the historic core of Malacca. While this is a jointinscription, this paper restricts its discussion to George Town alone. As depicted in Figure 1, George Town's heritage core constitutes 109.83ha, containing 2,344 buildings. This core is bounded by a 150.04 ha buffer zone containing 2,321 buildings. Within the core zone a number of key heritage sites are specifically identified including prominent religious sites, such as the Kuan Yin Temple, the Sri Mahamariamman Temple, the Kapitan Keling and Acheen Malay Mosques and the St. George Church. In addition, a range of socio-cultural sites, such as a number of kongsi or clan halls and the Clan Jetties, are identified.

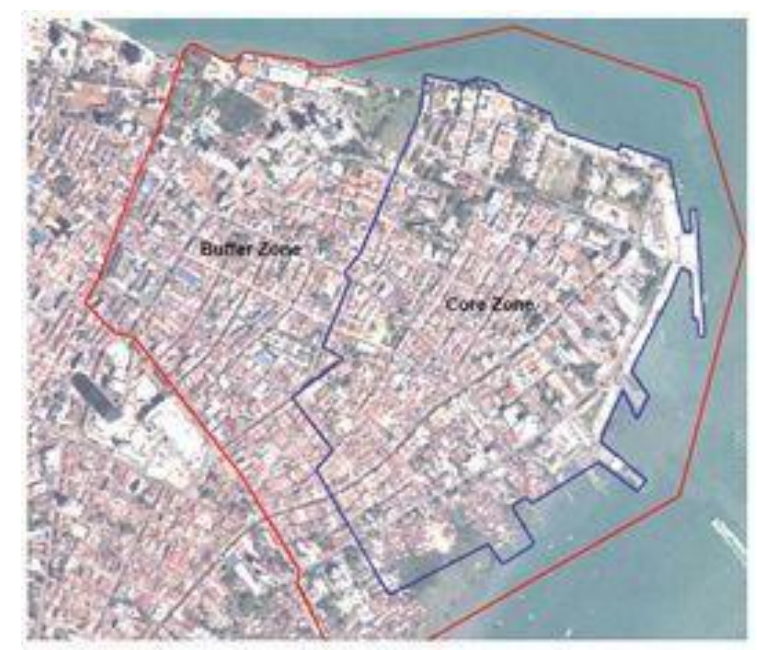

Figure 1. Aerial photograph of core and buffer zones of the historic city of George Town Source: Government of Malaysia 2007, p.16.

While the urban landscapes of the heritage cores of both cities are deserving of preservation, it is their rich and diverse cultural composition that marks them as globally unique. Reflecting this, George Town and Malacca were proposed and inscribed on the following grounds:

As living historic towns, both Melaka and George Town are still inhabited by people; the majority of them are descendants of the local groups that have inhabited the cities for generations. They are excellent examples of historic colonial towns on the Straits of Malacca that have endured and experienced a succession of historical events mostly related to their former function as trading ports linking the East and West. They are excellent examples of living heritage towns where multi-cultural heritage and tradition of South and East Asia coexistence; and where large examples of shophouses, in many different styles and cultural influences, can be found (Government of Malaysia 2007, p.109).

Here the entwining of tangible and intangible heritage is evident. George Town's core is not a static landscape of physical artefacts. Rather, it is a living cultural place. Balancing the needs of local communities with the opportunities and pressures of tourism development is a complex undertaking that vexes communities, government and nongovernment organisations. The following discussion $t$ critically considers these vexations. It discusses the competing pressures of heritage conservation and tourism promotion to tease out the double edge-sword of World Heritage designation within urban environments. Specifically, it discusses tourism visitations to Penang, the tendency for this to commodify not only places but also the people within them and the activities they undertake for the tourist market and how tourism changes the physical form of the built environment and its associated sense of place.

\section{Tourism in George Town: a double-edged sword}

It would be erroneous to assert that tourism in Penang in a recent phenomenon. The Island has been regarded as a popular destination, especially by elite western visitors, for well over a century. This is ratified by the establishment of the prestigious Eastern and Orient Hotel in 1885, which came to be considered as the height of colonial refinement. Having fallen into decline the $\mathrm{E} \& \mathrm{O}$, as it is commonly known, was renovated between 1996 and 2000. Peleggi (2005) has referred to this process, evident across Asia, as part of a resurgent 'colonial nostalgia' tourism movement. From the mid- 
Twentieth Century, Penang emerged as an essential destination on South East Asia's hippy trail and its antecedent back-packer trail. What attracted these groups to George Town was the areas 'authenticity'. Arguably, the impact of these tourist groups could be considered as quite benign to local populations or at least as having minimal disruptions. The majority of business established to service this tourism market constituted small scale guest houses or back-packer style hostels and bars. Befitting the thrifty nature of this style of tourism, meals were generally eaten at local street-hawkers carts located at various areas around the city. Thus, there was a mingling of locals and tourists in what could be considered an organic manner. This is not to assert that there were no negative impacts associated with these forms of tourism. Issues such as public drunkenness, viewed as a cultural affront by the Islamic population and associated anti-social behaviours were and still are evident and degrade the sense of place for many local people.

Penang therefore enjoys a long tourism tradition that has been steadily increasing in recent years. Table 1 details the annual tourist arrivals, differentiated as domestic and international tourism, from 2004 to 2014. This data, derived from counts of hotel guests at the State level compiled by the Malaysian Ministry of Tourism (see http://corporate.tourism.gov.my/research.asp? page $=$ facts_figures provides a longitudinal picture of tourism numbers and their changing nature. Generally, the data reveals that Penang has, for the past eight years, attracted high numbers of domestic and international visitors. Overall, growth in visitor numbers has been consistent. The data reveals 2008 and 2014 as peak years for domestic visitors. There has been much discussion about the impact of the 2006-2007 Avian Flu (H5N1 influenza strain), the 2009 Swine Flu (H1N1 influenza strain) and the 2007 global financial crisis (GFC) on international tourism. These three events combined had an undeniable impact upon both domestic and international tourism globally. However, data cited by Leggat et al. (2009, p.374) indicates that Australian tourists planning an overseas trip were more concerned about the GFC and how this impacted their economic capacity to travel as opposed to the health risk presented by the Swine Flu epidemic. Notwithstanding health alerts, Figure 1 indicates no discernible impact upon international visitations to Penang. In fact, from 2004 to 2011 there has been steady growth in international visitations numbers. In percentage change terms between 2004 and 2014 , domestic visitation grew by $67.7 \%$, international by $65.8 \%$ and total visitation by $66.8 \%$. These figures reveal extremely strong visitation growth and are indicative of Penang's standing as a major tourism destination. More importantly the data reveals a spike in visitation between 2007 and 2008 when the core of George Town was inscribed on the WH list. Between 2007 and 2008 a percentage change figure of $25.4 \%$ and $17.2 \%$ for domestic and international visitors respectively was recorded. Overall, total visitation grew by $21.6 \%$ between 2007 and 2008. These spikes can be anecdotally attributed to the WH listing. Thus it is plausible to assert that the HL has had a positive impact on tourist attraction in the case of Penang.

\begin{tabular}{|c|c|c|c|c|c|}
\hline \multirow{2}{*}{ Year } & \multicolumn{4}{|c|}{ Tourist Numbers } & \multirow{2}{*}{ Total } \\
\cline { 2 - 5 } & Domestic & \multicolumn{1}{|c|}{ International } & \multirow{2}{*}{} \\
\cline { 2 - 5 } & Number & $\%$ & Number & $\%$ & \\
\hline 2004 & $2,157,006$ & 52.5 & $1,948,822$ & 47.5 & $4,105,828$ \\
\hline 2005 & $2,267,532$ & 52.1 & $2,084,377$ & 47.9 & $4,351,909$ \\
\hline 2006 & $2,562,978$ & 54.4 & $2,152,256$ & 45.6 & $4,715,234$ \\
\hline 2007 & $2,787,260$ & 53.7 & $2,399,351$ & 46.3 & $5,186,611$ \\
\hline 2008 & $3,496,293$ & 55.4 & $2,811,175$ & 44.6 & $6,307,468$ \\
\hline 2009 & $2,982,687$ & 50.0 & $2,977,642$ & 50.0 & $5,960,329$ \\
\hline 2010 & $2,942,544$ & 49.1 & $3,048,320$ & 50.9 & $5,990,864$ \\
\hline 2011 & $2,956,390$ & 49.1 & $3,063,564$ & 50.9 & $6,019,954$ \\
\hline 2012 & $2,996,282$ & 49.2 & $3,096,907$ & 50.8 & $6,093,189$ \\
\hline 2013 & $2,639,182$ & 56.1 & $2,062,917$ & 43.9 & $4,702,099$ \\
\hline 2014 & $3,617,170$ & 52.8 & $3,230,399$ & 47.2 & $6,847,569$ \\
\hline $\begin{array}{c}\mathbf{2 0 0 4}- \\
\mathbf{2 0 1 4} \\
\text { Total }\end{array}$ & $31,405,324$ & 52.1 & $28,875,730$ & 47.9 & $60,281,054$ \\
\hline
\end{tabular}

Table 1. Tourist numbers for Penang State, 20042014

Source: Malaysian Ministry of Tourism hotel guests by locality data annual sets. See http://corporate.tourism.gov.my/research.asp?page =facts figures 
Such tourist numbers have an undeniable impact upon the social and physical environment of George Town. Given the modest size of the heritage core, tourist activities are spatially concentrated. Further, as a functioning urban core, there are obvious and competing forces at play. Examples of this are tensions around the commodification of daily activities undertaken by local people and the desire of tourists to witness and experience these activities as some form of 'authentic' performances. Large tourist groups can often be seen being guided through the city viewing not only key architectural and historic sites, but also daily human activities being undertaken in the course of local people's daily lives. These include the drawing of attention to people worshiping at the various religious sites and the undertaking of work practices classified as being 'traditional'. Figure 2 depicts one such group being shown a 'traditional craft', in this case a sign-carving business, as part of an organised heritage tour. In this specific example, no acknowledgement of the sign-carver was observed by either the tour guide or any tour participant. Rather, the group clustered around taking photos of the premises and signcarver, who interestingly was not carving but rather quietly reading, listening to the tour guide explain the activity undertaken at this site and how and why it constituted a 'traditional craft'. This exemplifies Jenkins' (2008: 247) concerns over the voyeuristic nature of cultural heritage tourism and how it commodifies the lives of local people for tourist consumption. Here, the notion of living museums comes sharply into relief. As tourism numbers grow the intrusion of voyeuristic activities will likely constitute an increasing imposition on the daily lives of local communities.

The increasingly commodified nature of George Town's heritage core has also witnessed changes in its physical form. Responding to the heritage tourism market niche tourism-oriented businesses have proliferated. Foremost amongst these is the redevelopment of shophouses as boutique hotels, art galleries and cafes/restaurants catering to a more affluent clientele. Since 2008 the number of boutique hotels and other tourism consumer services within the heritage core has expanded dramatically. Noted examples include 1881 Chong Tian Cultural Hotel, Campbell House, the Boutique Residence Hotel and the Straits Collection. The proliferation of such businesses is widely attributed to the WH inscription. As one prominent travel and cuisine website contends:

Following the UNESCO World Heritage Site inscription, Penang has become a hotbed for boutique hotels... International and renowned hoteliers... have transformed the hotel scenes in Penang by restoring heritage buildings and property into stylish and chic boutique hotels that put Penang on the hip list for affluent and upscale world travelers (Rasa Malaysia 2012, http://rasamalaysia.com/boutiquehotels-in-penang/).

Beyond the explicit acknowledgement of the $\mathrm{WH}$ inscription as the trigger for boutique hotel development, three other factors are interesting within this excerpt. The first is the WH inscription as constituting an affirmation of the areas global marketability and hence attracting international attention. The value of a given location is here subject to external perception and scrutiny. In this sense, WH constitutes little more than an external ratification of marketability as opposed to a measurement of heritage value. Second is the positioning of boutique hotels as preserving the city's tangible urban heritage. While it is undeniable that many such businesses undertake significant renovation of shophouses within the core, the extent to which renovation can be said to align with conservation is highly questionable (see Jenkins 2008). Renovation is not necessarily restoration. Third is the notion that such investment reframes the city as 'stylish and chic' and so placing it on the urban tourism 'hip list'. This comment resonates with Ashworth and Page's (2011) concerns over the capricious nature of urban tourism and the tendency for such tourism to revolve around check-lists of fashionable destinations which are vulnerable to changing fashions and trends. Fourth is that these changes cater for more 'affluent and upscale world travellers'. Here the notion of class comes to the fore. Whereas Penang was once a key destination on the hippy trail and backpacker circuit, the heritage core of George Town is perceived as 
having transformed into a more affluent, elite niche tourism landscape.

This transformation is witnessing numerous local households and businesses being replaced by boutique hotels and associated consumer-services. One specific example has been the 'upgrading' of Labuah Amenian. Prior to inscription, this street contained several family run recycling businesses, the majority of which have been displaced. Since the WH inscription the street, which is very close to a number of key heritage sites, has been significantly upgraded. Spearheading this transformation was the Straits Collection, which is marketed as a '...total eclectic mix of Retail, Restaurants and Residences located in the core zone of UNESCO Heritage Georgetown'(http://www.straitscollection.com .my/). The Straights Collection is in fact a spatially dispersed luxury development within the WH core. Beyond Amenian St, a series of five renovated shophouses are located in Stewart Lane, while China House in Beach St occupies an additional three shophouses. In total, the Straights Collection and associated developments now occupy ten shophouses. The Straights Collection and associated China House, is a salient example of the power of capital to transform local places into commodified spaces catering to affluent tourists at the expense of local people. Further, such projects serve as investment barometers. Having proven market buoyancy for such businesses, a number of similar boutique hotels and associated consumer services have opened in this specific area. Thus, such developments act as a beachhead, both proving that the potential for profitable investment exists and then serving as a locus for further redevelopment to cluster around and expand away from. These reinvestments not only significantly alter the physical character of George Town, but also alter its economic and social fabric. Here, the notion of living cultural heritage and its significance as envisaged under the WH inscription is called into question. The fundamental issue at hand is; whose interest does WH status serve, local people or tourists? Grave concerns must be expressed that the needs of the later are beginning to outweigh the former in George Town.

\section{Conclusion}

Urban tourism is a vibrant, if at this stage under-theorized, tourism market. The existing literature $\mathrm{t}$ provides an important foundation for future research into the opportunities and challenges such a market heralds for urban places. What is evident from this literature is that the purported benefits derived from urban tourism may well constitute marketing hyperbolae as opposed to being based on a rigorous evidence base. Ashworth and Page (2011) in particular stress this,contending that urban tourism is beset by a range of issues that problematise the claimed benefits of urban tourism development as a core economic policy direction., foremost amongst these are the site specific nature of such tourism, the short duration of visitations, the tendency of urban tourists to operate on a preset site checklist and the fickle and capricious nature of the urban tourism market. What these concerns illuminate is that the development of successful urban tourism markets is not a fait accompli. Rather, careful planning and management of such sites is required to ensure their long term sustainability. In particular, great care must be taken to ensure that the negative impacts stemming from urban tourism for local communities are minimised and/or mitigated.

Against this theoretical back-drop, this paper has explored WH tourism within urban context of George Town. This brief discussion reveals that the opportunities asserted to stem from WH tourism may well be out-shadowed by adverse impacts. George Town's inscription is founded on its role as a living cultural heritage site. There is a prevailing view that $\mathrm{WH}$ status provides a competitive advantage to designated places. George Town has long been a key tourism destination within South East Asia. Data presented here indicates that tourism numbers, both domestic and international, are increasing. Worthy of note is that tourism visitation has witnessed a spike following the inscription of George Town's core on the WHL. This suggests that WH status may well indeed positively influence tourist decision making processes. However, this chapter has also argued that $\mathrm{WH}$ oriented tourism is a double-edged sword. Echoing the earlier 
expressed concerns of Jenkins (2008), this chapter contends that aspects of George Town's social and economic fabric are being commodified. As commodities the daily practices inherent in George Town's inscription as a cultural heritage site become subject to voyeuristic tourist attention and scrutiny that over-time will undoubtedly negatively impinge upon the privacy and hence quality of life for local people and their communities. Further compounding this is the transformation of the area's built environment in order to cater to an increasingly affluent tourism market. Significant areas of the heritage core are experiencing the encroachment of boutique hotels and associated tourist consumer services. While some of these developments are small in scale and discrete within the urban fabric, others are not.
Often positioned as being necessary for the preservation of the areas architectural heritage, such developments undeniably cause displacement of existing residents and businesses. In all, caution must be exercised by governments in the pursuit of urban-based tourism endeavors. In the case of urban-based WH sites and their relationship with tourism economies greater caution must be exercised, for as Hede (2008: 134) has observed while ' $\mathrm{h}$ ] eritage and tourism appear to be strange bedfellows... there is increasing evidence of their coupling around the globe'. George Town constitutes and prime example of this strange and seemingly incompatible relationship. The concern is that George Town may well become a cautionary tale of the perils of such a relationship in the future if it continues down the path it is seemingly set upon.

\section{REFERENCES}

Ashworth, G. and Page, S.J. (2011) Urban tourism research: Recent progress and current paradoxes, Progress in Tourism Management, 32, 1-15.

Ashworth, G. J. (1989). Urban tourism: an imbalance in attention. In C. Cooper (Ed.) Progress in tourism, recreation and hospitality management, Vol. 1 (pp. 33-54). London: Belhaven.

Ashworth, G., and Tunbridge, J. (2000) The Tourist-Historic City: Retrospect and Prospect of Managing the Heritage City. Pergamon, Elsevier Science Ltd: Oxford.

Boniface, P. (1995) Managing Quality Cultural Tourism. Routledge, London.

Cameron, C. (2010) The unnatural history of heritage: what's the future for the past?, Journal of Heritage Tourism, 5/3, 203-218

Burtenshaw, D. Bateman, M. and Ashworth, G.J. (1991) The European city: A western perspective, David Fulton Publishers, London

Edwards, D., Griffin, T. and Hayllar, B. (2008) Urban Tourism Research: Developing an Agenda, Annals of Tourism Research, 35/4, 1032-1052

Fyall, A., and T. Rakic. (2006) "The Future Market for World Heritage Sites." In Leask and Fyall. A. (Eds) Managing World Heritage Sites. Butterworth-Heinemann: Oxford.

Garrod, B. and Fyall, A. (2000) Managing heritage tourism, Annals of Tourism Research, 27/3,682-708.

Hayllar, B., Griffin, A. and Edwards, D. (2008) (Eds) City Spaces-Tourist Places: Urban Tourism Precincts. Butterworth-Heinemann: Oxford. 
Hede, A-M. (2008) World Heritage Listing and the Evolving Issues Related to Tourism and Heritage: Cases from Australia and New Zealand, Journal of Heritage Tourism, 2/3, 133-144.

Jackson, P. (1993) Towards a cultural politics of consumption, in: Bird, J., Curtis, B., Putnam, T., Robertson, G. and Tickner, L. (eds) Mapping the Futures: Local Cultures, Global Change, 207-228. Routledge: London.

Jenkins, G. (2008) Contested Space: Cultural Heritage and Identity Reconstructions. Conservation Strategies within a Developing Asian City.

Karski, A. (1990) Urban Tourism: A Key to Urban Regeneration? The Planner, 76/13, 15-17.

Leggat, P.A., Speare, R, and Aitken, P. (2009) Swine Flu and Travelers: An Australian Perspective, Journal of Travel Medicine, 16/6, 373-376.

Li, M; Wu, B and Cai, L (2008) Tourism Development of World Heritage Sites in China: A Geographic Perspective. Tourism Management 29, 308-319.

Nin, K.S (2001) Streets of Georgetown, Penang. Janus Print and Resources: Penang, 12-22.

Page, S. (1995) Urban Tourism. London: Routledge.

Poria, Y., Reichel, A. and Cohen, R. (2011) World Heritage Site, Is It an Effective Brand Name?: A Case Study of a Religious Heritage Site, Journal of Travel Research, 50/5, 482-495.

Rofe, M.W., Diana Mohamad and Azizan Marzuki (2011) The complexities of social sustainability: balancing tradition and change in a UNESCO World Heritage site, in Roetman, P.E.J. and Daniels, C.B. (Eds) Creating Sustainable Communities in a Changing World, 95-102. Crawford House Publishing: Adelaide.

Williams, R. (1976) Keywords. Fontana: London.

Winchester, H.P.M and Rofe, M.W. (2005) Christmas in the 'Valley of Praise': Intersections of the rural idyll, heritage and community in Lobethal, South Australia, Journal of Rural Studies, 21, 265-279.

\footnotetext{
' It must be acknowledged that this data does not identify the nature of arrival visitation, for example as holiday, family visitation or business trips. This is particularly relevant for counts of domestic visitors. However, as the data sets are based on hotel stays it is sound to assume that visitations by domestic visitors are unlikely to be overly skewed as Malaysians generally tend to stay with family in private residences during such trips and so would be largely excluded from these surveys. Moreover, it must also be acknowledged that these data sets represent figures at the State level. However, as the highest proportion of hotel development within the State is clustered within George Town this data provides a sound indicator of tourism stays within this area. Overall, this data can be considered as providing a sound indication of visitor numbers to George Town.
} 